\title{
Om problemformuleringer i biblioteks-, dokumentations- og informationsvidenskab
}

\author{
Af Birger Hjørland
}

\begin{abstract}
Abstrakt
Denne artikel er et oplaeg om, hvad der er gode og frugtbare problemformuleringer i biblioteks-, dokumentations- og informationsvidenskab (BDI). Artiklen opbygger en dikotomi mellem selvstcendige universitetsopgaver på den ene side og common sense- behandlinger (eller "fristile") på den anden side. Den grundlaggende tese er, at al god forskning - og alle gode, selvstcendige universitetsopgaver-begynder og slutter i fagets litteratur. Det at vare professionel i et fag indebcerer bl.a., at man respekterer andre fag; kun derved tager man sig selv alvorligt som fagperson. BDI ses som et fag, der er teoretisk nødlidende og uudviklet. Ofte opfattes det fx som noget, der enten er en del af datalogien, eller som noget, der forsvinder, når datalogerne har udviklet de nødvendige systemer. Eller det ses på tilsvarende måde som del af kognitiv videnskab, medievidenskab, litteraturvidenskab osv. Denne tilstand gør det svcerere at lave gode problemformuleringer, men gør ikke sådanne mindre nødvendige. Enhver problemformulering er - bevidst eller ubevidst - en politisk handling, der på den lange bane er med til at bestemme BDIs udviklingsretning og fremtid.
\end{abstract}

Birger Hjørland er cand.psych., fil.dr og professor ved Det Informationsvidenskabelige Akademi (bh@iva.dk)

\section{Indledning}

Denne artikel omhandler studerendes og forskeres formuleringer af problemstillinger/ forskningsspørgsmål i studieopgaver og i forskningsartikler. Der er indtil nu skrevet meget lidt om problemformulering i biblioteks-, dokumentations- og informationsvidenskab (BDI). De vigtigste af de undersøgelser, der findes, refereres senere i denne artikel. I stedet for ligger det ofte implicit i fagets forskellige traditioner, hvordan problemer formuleres. Der er skrevet en del om problemformulering i den generelle opgavevejledende pædagogiske litteratur (fx Rienecker, 2005), og denne litteratur er der også trukket på i artiklen.

På et dybere plan er spørgsmålet om problemformuleringer knyttet til videnskabsteori og -sociologi, men det sker ofte meget implicit, og hvor der er en stor videnskabsteoretisk litteratur om at løse problemer, er der kun en meget begrænset litteratur om at formulere problemer (med Allwood \& Bärmark, 1999, som en meget vigtig undtagelse). Der er også eksempler på bidrag fra psykologien (fx Seidel, 1976), selvom også dette fag har arbejdet meget mere med menneskers problemløsning end med deres problemformulering og problembevidsthed.

Ideen til denne artikel udspringer især af mine erfaringer som intern censor på IVA, men jeg trækker også på baggrundsviden fra min egen forskning og på videnskabsteoretiske og -sociologiske studier. Artiklens hovedteser er, at gode problemformuleringer kræver god indlæsning i det fag, man skriver i, og at 
forskellige faglige perspektiver har forskellige idealer for gode problemformuleringer, hvorfor også bevidsthed om valg af fagligt perspektiv er væsentligt: Til syvende og sidst er gode problemformuleringer helt afhængige af et frugtbart teoretisk perspektiv.

\section{Biblioteks-, dokumentations- og informationsvi- denskab}

Biblioteks-, dokumentations- og informationsvidenskab (BDI) anvendes i denne artikel synonymt med "biblioteks- og informationsvidenskab", "informationsvidenskab" og "dokumentationsvidenskab". BDI har tidligere været anvendt som betegnelse for grundstudierne på det, der engang hed Danmarks Biblioteksskole, nu Det Informationsvidenskabelige Akademi (IVA). Aktuelt betegnes uddannelserne på IVA "Informationsvidenskab og kulturformidling". Der er altså - hvilket også gælder i internationalt perspektiv - en fluktuation i faget, allerede når det gælder dets betegnelse. Der hersker for øvrigt også uenighed om, hvorvidt BDI overhovedet er eller bør betragtes som et fag eller som et tværfagligt område eller noget tredje. Med hensyn til en oversigt over fagets mange forskellige betegnelser og deres historiske udvikling henvises til bilaget i den svenske evalueringsrapport redigeret af Carin Olausen (2004, side $99-135)^{1}$.

Er BDI et videnskabsfag? For at kunne besvare dette spørgsmål må man først svare på et andet spørgsmål: Hvad er en videnskab eller en akademisk disciplin? Man kan skelne mellem to bestemmelser:

1. Videnskab som et sociologisk fænomen bestående af ansatte forskere, forskningsinstitutioner, tidsskrifter, konferencer m.v. (videnskabens sociale dimension)

2. Videnskab som epistemologisk fænomen, dvs. noget, der lever op til normative krav for videnskabelighed med et selvstændigt genstandsfelt (videnskabens kognitive dimension).

Den sociale og den kognitive bestemmelse af begrebet videnskab spiller sammen, således at sociale dannelser er betinget af normative krav om videnskabelighed og omvendt. Dette er også en vigtig pointe i forbindelse med studerendes og forskeres problemformuleringer, fordi disse både må være fagligt relevante (den sociale dimension) og leve op til normer for videnskabelighed (den kognitive dimension). De to dimensioner i videnskab må spille sammen og enhver bestræbelse på at udvikle et fag bør bestræbe sig på at få de to bestemmelser til at gå op i en højere enhed.

BDI er klart en videnskab i første betydning, da der internationalt er etableret uddannelser, professorater, tidsskrifter, konferencer, og hvad der i øvrigt hører med til at være etableret i den sociologiske forstand. Hvorvidt BDI også er en videnskab i den filosofiske betydning af ordet, er et andet spørgsmål. Der er mange legitime forsknings- og undervisningsfelter, fx bibliotekshistorie, vidensorganisation, informationssøgning, børnekultur, informationskompetence osv. Men spørgsmålet er, hvordan de hænger teoretisk sammen, og hvad deres grundbegreber er? Betegnelsen "bibliotekshistorie" tyder på, at begrebet "bibliotek" (forstået som en institution) er grundbegrebet. Vidensorganisation tyder på, at det er begrebet viden, der er grundbegrebet. Betegnelser som informationssøgning og informationskompetence tyder på, at det er informationsbegrebet, der er det centrale (hvilket jo passer med navnet IVA). Betegnelsen børnekultur peger på kulturbegrebet (samt på begreberne litteratur og medier). Fagets historiske navneskift ( $\mathrm{f} x$ fra biblioteksvidenskab til informationsvidenskab) er relateret til forskellige prioriteringer af disse og andre begreber.

Forskerne på BDI-institutioner er dels uddannet inden for BDI, dels i andre fag (fx datalogi, sociologi eller litteraturvidenskab). De forskere, der er uddannet inden for BDI, tenderer imod at publicere i BDI-faglige tidsskrifter, deltage i BDI-faglige konferencer etc. De tenderer imod at betragte BDI som et fag og imod at udgøre centripetale ${ }^{2}$ kræfter, dvs. kræfter, der forsøger at samle faget (på bekostning af at publicere i andre faglige kontekster). Det samme kan være tilfældet med de mennesker, der er uddannet $i$ andre fag, men de kan også vælge at publicere andre steder, deltage i andre konferencer og måske imod at udgøre centrifugale kræfter, dvs. kræfter, der forsøger at forstå BDI-faglige problemer ud fra en anden faglig kontekst og knytte an til de videnskabsområder, hvori de oprindeligt er uddannede (og som de måske, måske ikke, vil søge over i, hvis lejligheden byder sig). Et givet fag, også BDI, er derfor en slagmark, hvor forskellige interesser kæmper mod hinanden. Fagets identitet og overlevelse er afhængig af, at tilstrækkeligt mange arbejder på at styrke faget, såvel dets kognitive som dets sociale dimensio- 
ner. Det er også vigtigt at fremhæve, at BDI har brug for tværfagligt input og dermed den dobbelthed, der ligger i at arbejde i flere faglige kontekster. Den ideelle fagperson har såvel BDI-faglige som specifikke kompetencer i andre videnskabsområder.

Er BDI et fag eller fx et tværfagligt forskningsområde? Emin Tengström (1993, side 12) adskiller tre ambitionsniveauer i den tværfaglige forskning:

1. Det fler-, multi- eller pluridisciplinære niveau indebærer, at en gruppe forskere deltager i samme projekt med et afgrænset tema, men hver især har udgangspunkt i sin egen disciplin.

2. Det genuint tværfaglige niveau indebærer, at forskernes strikte faglighed modificeres. Teorier og modeller fra andre discipliner anvendes på det nye område.

3. På det disciplindannende eller transdisciplinære niveau dannes nye begreber, og selvstændige teorier for feltet vokser frem. Nye discipliner kan fx opstå ved afsnøring af specialer fra moderdisciplinen eller ved, at to etablerede discipliner udvikler grænseområdet til en ny videnskab (fx biokemi ud fra biologi og kemi). Med etablerede fag menes discipliner, der holdes sammen af en intellektuel tradition, af et fælles begrebsapparat og dertil knyttede modeller og teorier.

Tengström beskriver med andre ord vidensområder som sociale felter, der er dynamiske og under stadig udvikling. BDI kan fx ses som et forskningsområde, der er grundlagt som et flerdisciplinært område baseret på bl.a. litteraturvidenskab, psykologi, sociologi, management og datalogi, men som er på vej til at udvikle sig til en selvstændig videnskab. Bemærk at BDI på samme tid kan ses som en disciplin og en "interdisciplin." Den er en interdisciplin i sin afhængighed af andre fags teorier og metoder. Den er en disciplin i kraft af sine etablerede læreanstalter, forskningstidsskrifter og videnskabelige konferencer.

Der hersker en ret stor uenighed inden for BDI med hensyn til såvel, hvordan faget skal betegnes, som hvad der udgør dets centrale begreber og teorier, vigtige grænseområder, m.v. (jf. fx Pettigrew \& McKechnie, 2001; McKechnie \& Pettigrew, 2002). Dette relaterer sig også til fagets institutionelle tilhørsforhold: fra en helt selvstændig eller fritstående institution til variationer ( $\mathrm{fx}$ i Sverige), hvor BDI-institutionerne er knyttet til forskellige fakulteter og kan høre sammen med fx kommunikationsforskning, pædagogik, datalogi mv. Sådanne forhold har indflydelse på den måde, hvorpå man formulerer problemer.

Det er ikke ligegyldigt for hverken fagets eller opgaveskriverens/forskerens fremtid, hvordan man stiller sig til sådanne metateoretiske spørgsmål. Vi kommer lidt ind på disse problemer senere $\mathrm{i}$ artiklen, men det er naturligvis nødvendigt at forholde sig til en bredere litteratur herom. Problemformuleringen skal med andre ord også motivere, hvorfor en given analyse er interessant for feltet, dvs. hvordan den bidrager til fagets udvikling og dermed klart udtrykke, hvorfor den givne undersøgelse er gennemført.

BDI kan altså ses mere eller mindre som noget allerede etableret eller som noget, der er under udvikling. Et fag eller en interdisciplin kan ikke eksistere eller udvikles uafhængigt af den forskning, der bedrives i dets navn. Derfor er forskningsspørgsmål eller problemformuleringer med til at bestemme fagets fremtid - og dermed repræsenterer de altid (fag)politiske handlinger, hvad enten ophavspersonerne er sig det bevidst eller ej.

\section{Om problemformuleringer eller forsknings- spørgsmål}

Brewer \& Hunter (2006, side 39) definerer forskningsproblemer på denne måde:

"Research problems are questions that indicate gaps in the scope or the certainty of our knowledge. They point either to problematic phenomena, observed events that are puzzling in terms of our currently accepted ideas, or to problematic theories, current ideas that are challenged by new hypotheses."

Rienecker (2005, side 20) skriver om den gode problemformulering:

"Den vigtigste forudsætning for at en problemformulering er god, er selvfølgelig at den indholdsmæssigt stiller et spørgsmål inden for det pågældende fag som forekommer såvel den studerende som vejlederen meningsfyldt".

Synspunktet i disse citater deles også af $\mathrm{Hernon}^{3}$ \& Schwartz (2007, side 308): "the proposed research 
should contribute to the literature of the profession and perhaps beyond."

Ovennævnte citater forudsætter, at problemformuleringer stilles inden for et fag, og at der er en klarhed over, hvad dette fag er. Dette indebærer, at det at kunne trække viden fra et andet fag i sig selv kan være et bidrag. Det kræver igen, at opgaveskriveren/forskeren kan se, at denne fremmede viden kan bidrage positivt og ikke er triviel viden i faget. Det kræver derfor såvel kendskab til den fremmede viden som til det fagområde, hvori den introduceres.

Forskning og selvstændige universitetsopgaver går altså ikke ud på at vise, hvor dygtig eller lærd forfatteren er, men på at bidrage til løsning af relevante problemer (hvorved forfatteren indirekte demonstrere sine evner ved at mestre at identificere og bidrage til at løse eller belyse et problem) ${ }^{4}$. Det er klart, at der findes opgavetyper, der består $\mathrm{i}$ indlæring af $\mathrm{fx}$ konkrete metoder eller systemer, men her taler vi om selvstændige opgaver og forskningsarbejder, hvor forfatteren selv vælger emne og metode. Sådanne selvstændige opgaver er modelleret over forskningsarbejder og vurderes efter samme kriterier, selv om der naturligvis altid tages hensyn til uddannelsesniveauet. Mange universitetsopgaver er fremragende og tåler bestemt sammenligning med professionel forskning. Men igen: Kriteriet for kvaliteten af opgaver er ikke, hvor belæst forfatteren er, hvor mange sider vedkommende skriver, hvilke teorier der behandles, eller hvor mange tekster, der citeres $i$ referencelisten. Alt dette er i bedste fald indirekte kriterier for det egentlige: hvilke problemer man bidrager til at løse og om ens arbejde til syvende og sidst er de resurser værd, som samfundet og en selv investerer i det.

Det modsatte af et bidrag - et antibidrag - er en tekst, som spilder tiden for læseren (dvs. brugere af fagets tekster). Hvis en artikel ikke har gjort sit hjemmearbejde og derfor ikke har fundet frem til de bidrag, der er de væsentligste ud fra artiklens perspektiv, men blot fx reproducerer andres problematiske forståelser, så udgør den et antibidrag. En typisk form for antibidrag er empiriske eller teoretiske arbejder der bygger på problematiske antagelser, som der måske allerede er publiceret væsentlige argumenter imod, men som man ikke kender, fordi man ikke har gjort sit hjemmearbejde ordentligt. En anden form for antibidrag er unødvendig henvisning til og brug af litteratur (fx for at vise hvor belæst man er) eller introduktion af emner, der reelt ikke spiller en rolle for konklusionen. Det er et udbredt problem, at meget faglitteratur bruger namedropping (eller citazionismo ${ }^{5}$ ), dvs. anvender mange navne ( $\mathrm{fx}$ i form af litteraturhenvisninger) i forbifarten uden rigtigt at introducere disse eller gøre brug af dem. Dette kan sammenlignes med "spam" og en forskningslitteratur, hvor de forskellige bidragydere ikke er ordentligt læst ind i faget, kan sammenlignes med et dårligt ledet chatroom, hvor alle taler i munden på hinanden uden først at høre, hvad der allerede er blevet sagt.

For at kunne bidrage til løsning af et problem må man kunne formulere det problem, opgaven/forskningen skal bidrage til. Dette kaldes forskningsspørgsmålene eller problemformulering. I den videnskabelige metodelære og i videnskabsteorien har fokus ofte været på, hvor godt forskeren er i stand til at argumentere for sine svar, mens undersøgelser af naturen, udviklingen og kvaliteten af forskningsspørgsmålene har været forsømt (jf. Allwood \& Bärmark, 1999). Samme artikel refererer nogle videnskabsteoretiske positioner til problemformulering:

\footnotetext{
"According to Popper (1972, p. 81) problems should be bold in the sense that the hypothesis implicitly stated in the problem should be highly refutable. Popper thus belittled the routine researcher who prefers to formulate undaring hypotheses in order not to have them refuted. In a parallel manner, Albert Einstein expressed a condescending view of the researcher who doesn't accept great challenges when it comes to a renewal of research problems. 'I have little patience', said Einstein, ' with scientists who take a board of wood, look for its thinnest part, and drill a great number of holes where drilling is easy' (quoted in Gardener, 1993, p. 106).
}

According to Kuhn (1962), conducting routine research, what he describes as 'normal science', has much in common with the solving of puzzles. The researcher drills, as Einstein said, where the board is at its thinnest, where there already exist elaborated methods, categories as well as established theories." (Allwood \& Bärmark, 1999, side 61).

Karl Popper fremhævede altså, at forskningsspørgsmålene for det første skal være så klart formulerede, at det er muligt entydigt at afgøre, om de er besvarede eller ej. For det andet skal de være væsentlige og 
dristige. Også Einstein påpeger, at der ikke er vundet meget ved at undersøge noget, der giver sig selv.

Thomas Kuhn skelner som bekendt mellem på den ene side normalvidenskab, der er styret af antagelser i et "paradigme" (og hvor forskningsspørgsmålene næsten giver sig selv, og der allerede er udviklet metoder, begreber og teorier) og på den anden side præ-paradigmatisk videnskab eller videnskab i krise, hvor problemformuleringen er vanskelig, og hvor de nødvendige metoder, begreber, teorier og forskningsspørgsmål forudsætter dannelsen af et "paradigme." Den måde de fleste i dag taler om "paradigmer" drejer sig i modsætning til Kuhn om samtidige, konkurrerende forskningsprogrammer baseret på forskellige filosofiske grundantagelser, og hvor forskningsspørgsmål derfor altid er indlejret i og afspejler relationer til grundlæggende teoretiske spørgsmål.

Sådanne teoretiske spørgsmål kan man ikke hæve sig op over. Thomas Wiben Jensen skriver:

"Eksempelvis vil en common sense betragtning over et givent emne som regel være præget af en stræben efter at inkludere flere aspekter, der umiddelbart forekommer rimelige, men som måske ved en nærmere granskning ville vise sig at være inkonsistente. En videnskabelig tilgang derimod arbejder ud fra helt andre præmisser, der fordrer en grad af stringens, som resulterer i, at man i højere grad bliver nødt til at medtage konsekvenserne af et standpunkt og i den forstand rendyrke sit perspektiv. Fagmanden er nødt til at være selektiv og dermed ofte vælge ét perspektiv og tænke dette perspektiv igennem i en sådan grad, at det til en vis grad kommer til at udelukke andre perspektiver. Det er prisen for at sige noget præcist". (Wiben Jensen, 2011, side 18-19)

Det, der siges her, er altså, at teoretisk ensidighed ikke nødvendigvis er en svaghed, men kan være en nødvendighed. Det er ikke stedet i denne artikel at gå i dybden med BDI-fagets "paradigmer," forskningstraditioner eller faglige perspektiver, men det er et uhyre centralt felt, fordi forskningsspørgsmål altid - bevidst eller ubevidst - er præget af forskerens eller opgaveskriverens syn på feltet. Med hermeneutikkens ord: Af deres forforståelse og "for-domme". Jo mere bevidst valget af fagligt perspektiv er, desto større er chancen for, at de er af høj kvalitet og relevans.

\section{Forskellen mellem en selvstændig faglig opgave og en "fristil"}

Forskellen mellem på den ene side common sensebetragtninger (en "fristil") og på den anden side en selvstændig opgave på en videregående uddannelse er, at sidstnævnte forholder sig til fagets teoretiske diskurser. Dette er et grundtræk ved akademisk virksomhed. Eller med andre ord: al god forskning - og alle gode, selvstændige universitetsopgaver begynder og slutter i fagets litteratur. Det kræver simpelthen megen faglig viden at kunne udarbejde gode forskningsspørgsmål/-problemformuleringer. Problemformuleringen er altså ikke noget, man i sidste øjeblik griber ud af luften og derefter går i gang med det egentlige arbejde. Problemformulering er derimod noget, der kræver en god indlæsning - og også kreativitet med at finde noget, der er egnet, dvs. noget, der såvel er relevant og vigtigt som gennemførligt ( $\mathrm{fx}$ som empirisk, teoretisk eller historisk projekt).

Det, der her bevidst nedladende er kaldt "fristile" vil først blive eksemplificeret med en hypotetisk opgave i faget "vidensformidlende institutioner". Såfremt studerende hver vælger en institution, fx Museum Jorn, og en metode, fx interviewmetoden, læser lidt om begge dele, laver et interview med personalet på Museum Jorn, og det er det, så er problemstillingen ikke noget, der er afledt af et vigtigt forskningsproblem i faglitteraturen om vidensformidlende institutioner.

Det er derfor vigtigt at inddrage og forholde sig til den almene teori om vidensformidlende institutioner, fx stille spørgsmålene: "Hvorfor er et kunstmuseum i grunden en vidensformidlende institution?", og "hvad slags teori er frugtbar for at belyse vidensformidlende institutioner ud fra et BDI-perspektiv? Det er ikke blot et spørgsmål om at vælge en eller anden teori. Hvis man - fx af mangel på overblik - vælger en mindre frugtbar teori, så er der også dårligere chancer for at lave en frugtbar opgave . $^{6}$

Et givent forskningsobjekt, $\mathrm{fx}$ et kunstmuseum, kan være genstand for mange forskellige faglige perspektiver, fx arkitektoniske, historiske, politiske, juridiske, økonomiske, kultursociologiske, og ledelsesmæssige opgaver og undersøgelser. Det er vigtigt, at BDI- studerende finder et unikt BDI-perspektiv, og 
ikke blot udfører et amatørarbejde indenfor andre fagområder, dvs. en "fristil".

Vi kan også eksemplificere med opgaver om automatisk indeksering. Det er populært at skrive opgaver/ lave forskning, der undersøger visse programmer til automatisk indeksering (fx "AlchemyAPI" og "Zemanta") på et empirisk materiale. Ofte inddrages visse generelle arbejder om vidensorganisation. Men pointen er, at det akademiske arbejde bør være baseret på vores viden om automatisk indeksering, og empiriske undersøgelser bør forholde sig til teoretiske problemer og være med til at udvikle vores teoretiske forståelse for automatisk og manuel indeksering (og fx forholde sig til artikler som Diepeveen, Fassbender \& Robertson, 2007). Det er naturligvis nyttigt at beherske edb-programmer til automatisk indeksering, men denne tekniske viden er ikke i sig selv det centrale, når man arbejder med faglige problemer. Den er kun en forudsætning for det empiriske arbejde.

Det er som sagt ikke nok at finde et eller andet fagligt perspektiv. Man skal finde et perspektiv, der er med til at udvikle ens professionelle profil og kompetence, og som man kan bygge videre på i fremtidige studie- eller forskningsopgaver. På sigt skal man finde opgaver, som er relevante i et samfundsmæssigt perspektiv og er med til at udvikle BDI og skabe fremtidige arbejdspladser. Det er ikke blot den individuelle opgaveskrivers ansvar at finde frugtbare teorier. Det er også undervisernes ansvar og til syvende og sidst alle forskeres og underviseres ansvar. Undervisningen skal introducere frugtbare teorier og åbne perspektiver for fremtidige forskningsarbejder. Det er vigtigt at erkende dette og ikke forvente undervisning, der blot leverer svar, men ikke stiller spørgsmål. Udviklingen af et fagområde er et kollektivt ansvar, der er afhængigt af individers engagement, ambitioner og grundige arbejde. Derfor bør vi alle starte med os selv og ikke stille mindre krav til os selv, end vi stiller til andre.

Med hensyn til valg af teorier og perspektiver kan valget $\mathrm{i}$ begyndelsen synes let, fordi det forekommer, at der er så meget at vælge imellem. Men når man undersøger dem nøjere, indskrænkes puljen af brugbare teorier og perspektiver, så man kan stå frustreret tilbage af mangel på et perspektiv, der forekommer tilstrækkeligt frugtbart ${ }^{7}$. Det er i denne proces vigtigt at gå frem og tilbage mellem det abstrakte og kon- krete. En abstrakt teori falder måske igennem, hvis den afprøves i en konkret kontekst ${ }^{8}$ - og omvendt må muligheden for at bidrage til en helt konkret kontekst ofte opgives eller modificeres, fordi det kræver helt andre ting, end den akademiske faglighed man har mulighed for at udvikle. Alligevel er det vigtigt at fastholde, at det akademiske arbejde skal have klare praktiske og konkrete implikationer. Det er også vigtigt kritisk at undersøge grundlaget for de teorier, man bygger på. Som Michael Buckland skriver:

"To be scholarly involves more than being knowledgeable. It requires the affirmative search for evidence contrary to one's theories. [...] In this context, being critical is not a matter of being hostile or negative, but of asking questions about underlying assumptions and methodological choices. How have conclusions been determined, or at least influenced, by particular assumptions or the choice of method? The ideal is to be scientific and scholarly and critical. The more we can approach that ideal the more robust our ideas will be." (Buckland, 2012, p. 1)

Allwood \& Bärmark (1999, side 61) nævner også, at privat succes for den enkelte forsker/studerende nogle gange er vigtigere for ham eller hende end problemstillingens videnskabelige relevans. Man kan være fristet til at vælge et bestemt teoretisk perspektiv for at vinde allierede (eller for at please sin lærer eller undgå at blive upopulær). Det er naturligvis ødelæggende for en akademisk kultur, hvis forskernes og de studerendes muligheder for at undersøge og identificere de bedste faglige teorier og perspektiver undergraves af klikedannelser og uakademiske normer og magtkampe. Dette ligger også i Bucklands krav om at være videnskabelig, akademisk og kritisk.

Nødvendigheden af at tage udgangspunkt i fagets litteratur kan også belyses ved det, som bogen Den gode opgave betegner som strategisk fortielse. Forfatterne skriver:

"Kan man tillade sig at lade som om kilder ikke eksisterer? Nej, det er ikke videnskabelig fremgangsmåde at lade som om kilder, der udtømmer hvad man selv ville have skrevet om et emne, slet ikke findes (og så håbe på at vejleder og censor ikke kender dem). Det er også et spørgsmål vi har fået mange gange fra studerende der har opdaget en kilde der skriver alt det de selv havde tænkt sig. 
Ville det bedste ikke vare at stille den tilbage, evt. slet ikke loese den? Selvom det er ærgerligt, må man vinkle sit eget stof så man anerkender den litteratur man er opmærksom på eksistensen af, og så man ikke fuldstændigt gentager noget allerede publiceret. Der må ikke være mistanke om hverken plagiat eller strategiske fortielser. Idealet er hele tiden at man anerkender og bygger oven på andres publikationer. At det sker at studerende (og forskere!) ikke sjældent får den oplevelse at andre er kommet først med stof, er et argument for hvorfor det har store fordele at fortolke/forklare/konstruere nyt materiale i opgaven og for at indlede valg af problem med orienterende litteratursøgninger" (Reinecker \& Stray Jørgensen, 2010, side 216-17; her tilføjet fremhævninger).

Strategisk fortielse og fordrejning af ophav til ideer er naturligvis uetisk, men også uvidenskabeligt: Selv om man kan løse et problem, er den historiske kontekst ikke videnskaben uvedkommende, fordi målet for den videnskabelige virksomhed er at skrive viden ind i sin faglige kontekst. Hvis man sløser med dette, så havner man i et morads af modstridende og usammenhængende oplysninger og kan ikke skelne skidt fra kanel.

\section{BDI-faget som kontekst}

Vi så i introduktionsafsnittet, at BDI både kan ses som en disciplin og en interdisciplin. Som en reaktion på en tidligere version af denne artikel skrev en kollega:

" [Jeg vil] bede dig overveje, om ikke kriteriet teoretisk evne/højde (frem for at konsultere specifikke ${ }^{9}$ tidsskrifter) kunne være et bedre og mere sandsynligt kriterie for succes i en videnskabelig sammenhæng? Jeg synes altså at du bør undlade en lidt "katolsk" omgang med kilder, som om de studerende kun kan finde relevante ideer i bestemte tidsskrifter. Faktisk mener jeg at mange af disse artikler ikke er så teoretisk stærke og holdbare. [...] Argumentet med at der p.t. er etableret lærestole, tidsskrifter m.v. inden for BDI mener jeg ikke er så vægtigt. Historien er fuld af eksempler på, at discipliner kan omdefineres, og at deres vidensformer kan integreres i andre felter" (Anonym; uformel kommunikation 2011-12-26).
Hvad dette citat siger, er at de tidsskrifter og diskurser, der udgør dele af BDI forstået som en etableret disciplin "ikke er så teoretisk stærke og holdbare" og dermed ikke bør forlanges som baggrundsviden for problemformuleringer i faget. Videre siges det, at BDI- faget kan omdefineres og integreres i andre felter (Datalogi? Kognitiv videnskab? Litteraturvidenskab? Medievidenskab?). Ja, naturligvis kan det sidste ske, men det, vi er sammen om i BDI (og fx på IVA), er vel netop at bidrage til at løse problemer, som efter vores mening ikke blot kan varetages inden for andre eksisterende rammer? Og det at arbejde for at udvikle BDI indebærer, som vi så tidligere, såvel et arbejde for etablerede strukturer (bl.a. tidsskrifter og stillinger) som for frugtbare teorier, begreber og metoder. Hvis den eksisterende BDI-viden er for svag og uholdbar, så må vi vel argumentere for bedre alternativer? Og hvis det er et akademisk ideal at søge dialog, så er det vel også et ideal at søge at vinde indflydelse for vore synspunkter, bl.a. i de BDIfaglige tidsskrifter og -konferencer. Jeg har derfor svært ved at forstå det synspunkt, at dette er noget, man kan vælge at se bort fra. Hvis man mener, at et bestemt perspektiv er relevant for BDI, så er opgaven jo netop at argumentere herfor i den BDI-mæssige kontekst og søge indflydelse for sine synspunkter i de etablerede strukturer - ultimativt at vinde magten over dem.

BDI-teori er generelt nødlidende, hvilket fx Buckland (2012) og ovenstående anonyme citat udtrykker. At det forholder sig sådan gør naturligvis kravet om ikke at skrive fristile større for både studerende, undervisere og forskere. Men tilføringen af et nyt synspunkt må indebære den kritiske analyse af det, man argumenterer imod (som Buckland blev citeret for). Målet er teoretisk klarhed, ikke en jungle, hvor hver især kan have sine private meninger, anvende idiosynkratiske begreber og blot dyrke sine private interesser uden interesse for helheden.

At forstå BDI er også at respektere andre fag: Kun ved at tage dem alvorligt tager man sig selv seriøst. BDI er naturligvis ikke et fag, der eksisterer i en færdig form. Alle fag er altid i proces. Og i denne proces er der kræfter, der arbejder i forskellige retninger, herunder såvel centripetale som centrifugale kræfter, dvs. kræfter, der henholdsvis forsøger at samle faget versus at sprede faget, altså henføre dets genstande under andre fag. At vælge problemstillinger er derfor også at vælge standpunkt mht. til fagets ønskelige 
udvikling: Hvis man fx vælger at lave en analyse af en film, der er baseret på filmteori og ikke relaterer sig til BDI-teori, så styrker man fagets centrifugale kræfter. Hvis man derimod argumenterer for, at filmteori er frugtbart i en BDI-kontekst, så kan man medvirke til at styrke de centripetale kræfter, hvis man også arbejder med bredere familier af relevante teorier i relation til BDI.

Det følger efter min opfattelse, at problemformuleringer må baseres på kendskab til såvel BDI-fagets etablerede litteratur som til viden fra andre fag. Gerne på den måde at forskning $\mathrm{i}$ fagets litteratur problematiseres ved at belyse det med forskning fra andre discipliner. Men hvis denne relation mangler, er der jo intet vundet ved at finde frugtbare teorier i andre discipliner, idet man så hverken bidrager til BDI eller til disse andre discipliner. Det, at sætte sig ind i et begreb eller en teori fra et andet fag, kan være et stort arbejde, men man risikerer let at havne mellem to stole, hvor man ikke bidrager til hverken det ene eller det andet fag ${ }^{10}$.

Da universitetsfag skal være forskningsbaserede, og da forskning er et internationalt foretagende, følger også, at teoretiske argumenter i og om BDI bør publiceres internationalt, og at undervisningen bør afspejle fagets internationale diskurser. Det er den eneste måde, man kan afprøve sine præmisser og argumenter: ved at udsætte dem for den mest kvalificerede kritik, der findes.

\section{BDI-teori}

Der er i efteråret 2011 på IVA udkommet hele to store værker om (fysiske) biblioteker: Dahlkild (2011) og Jochumsen, Skot-Hansen \& Hvenegaard (2011). Problemformuleringer er investeringer i fremtiden, og vores relation til bl.a. biblioteksbegrebet er ret afgørende for, hvad vi arbejder frem imod. Samtidigt med dette fokus på fysiske biblioteker leverede fx Cotta-Schønberg (2009) en analyse af forskningsbibliotekernes udfordringer. Med hensyn til folkebibliotekerne leverede Huymans \& Hillebrink (2008) en skarp analyse. Det er begge analyser, der ser fysiske biblioteker som en truet art, men som også har konstruktive bud på, hvad vi skal gøre, hvis vi vil kæmpe for at bevare dem. Det er således klart, at nogle forskere på IVA tager udgangspunkt i det fysiske bibliotek, mens andre satser på udvikling af tjenester, der er uafhængige af fysiske biblioteker (fx videns- organisation, informationskompetence, forskningsevaluering og kildekritik). Pointen er her, at fysiske biblioteker er truede, og at problemformuleringer enten kan tage udgangspunkt i problemer, der forsvarer deres eksistens, eller tage udgangspunkt $i$ en fremtid, hvor folk finder deres dokumenter og information direkte fra deres skrivebord eller mobiltelefon, men det er vigtigt at vide hvad man satser på. Hvis man satser på alternativer til det fysiske bibliotek, er det vigtigt, at begrebet om dette ikke spærrer for ens innovation ved, at man ikke har tænkt tanken igennem og konsekvent baseret sine studier herpå. Forskere, der arbejder med basis i fysiske folkebiblioteker ( $\mathrm{fx}$ Audunson, 2005), kan fx gøre dette ud fra et fremtidsperspektiv om udvikling af lav-intensive væresteder. Dette er uden tvivl også en vigtig funktion at have for øje. Men det er jo ret uambitiøst sammenlignet med visioner om biblioteket som en fortsat hovedhjørnesten i videnssamfundet ${ }^{11}$. Derfor er mit forslag at prioritere emner, som er mere i tråd med BDI-fagets informations- og vidensformidlende rolle (igen $\mathrm{fx}$ vidensorganisation, informationskompetence og kildekritik). Til dette formål er Jack Andersens (2011) karakteristik af BDI et frugtbart teoretisk udgangspunkt:

"Biblioteks- og informations-videnskaben kan [...] opfattes som studiet af samfundets vidensproduktion, som den materialiserer sig i dokumenter af enhver art, og af igennem hvilke systemer, institutioner og medier denne viden bliver kommunikeret og hvordan man kan sikre adgangen til denne viden i form af organisation og repræsentation af dokumenter."

Dette er på den ene side er en god og rummelig definition, som alle kan forholde sig til, og som på den anden side et tilstrækkelig fokuseret til at give BDI-undervisning og -forskning en klar retning og afgrænsning $\mathrm{i}$ forhold til andre fag.

BDI beskæftiger sig således med vidensproducerende og vidensformidlende systemer og processer samt med de vidensproducerende og -formidlende institutioner og medier. Hertil kommer, at denne forskning nødvendigvis også omfatter de implicitte eller eksplicitte kvalitets- og relevansnormer, der er for den vidensproduktion og formidling, der ligger til grund for disse systemer og processer. Det at have dette almene perspektiv med, også når man arbejder på det konkrete niveau (fx Museum Jorn) er vigtigt. 
Det kan vi ikke gå i dybden med her, men pointen er, at det er vigtigt, at enhver opgave er baseret på et sådant fagligt-teoretisk grundlag.

BDI-fagets og IVAs unikke faglighed kan eksemplificeres ved søgemaskiner som Google. Søgemaskiner betragtes ofte som rent datalogiske objekter og som teknologier, der optimeres efter "neutrale" og "objektive" principper. Men dette er i videnskabsteoretisk og videnskabssociologisk perspektiv et problematisk synspunkt. Enhver søgemaskine og enhver form for vidensorganisation gør nogle ting relativt mere synlige og lettere genfindelige end andre. Man kan sige, at der altid ligger kulturpolitiske eller videnskabsteoretiske implikationer bag en søgemaskine (jf. Hjørland, 2012b). Vi på IVA har dels forskere, der går langt ind i de tekniske aspekter af søgemaskiner, og forskere, der går langt ind i det kulturpolitiske og videnskabsteoretiske. Det er netop den kombination, der på den ene side er unik, og på den anden side rummer et klart relevant samfundsmæssigt perspektiv. Det vil være godt, hvis dette unikke perspektiv kunne afspejle sig i en del af problemformuleringerne, selvom der naturligvis også skal være plads til problemformuleringer, der kun indirekte bidrager til dette unikke fokus.

\section{Konklusion}

Problemstillinger indenfor BDI bør baseres på fagets litteratur, traditioner og grundlæggende antagelser og forholde sig til metateoretiske og videnskabsteoretiske positioner. Der er et klart behov for et opgør med mange antagelser og tilgange til faget, men introduktion af nye perspektiver bør baseres på kendskab og stillingtagen til fagets historie, forskellige tilgange og udfordringer, herunder udfordringer fra IT. Det kan være fristende blot at beskæftige sig med noget, der forekommer stærkt og brugbart uanset faglig kontekst. Der er mange ting, det er godt at kunne, ikke mindst for jobsøgere. Dette gælder ikke mindst IT. Sidstnævnte kan forekomme langt mere avanceret og brugbart end BDI, men vores fagområde er et andet. Det samme gælder vores samfundsmæssige rolle. BDI-fagets rolle er snarere at arbejde med kvalitative kriterier for informations- og kulturformidling, som IT-folkene så evt. kan omsætte til algoritmer (se også Hjørland, 2012c for et syn på fagets rolle). En frugtbar teori er én, der peger på vigtige uløste problemer, som $v i$ kan være med til at løse.
Risikoen er at BDI-faget forbliver det, Åström (2006, baseret på Whitley, 1984) har kaldt et fragmenteret adhockrati, dvs. et fag uden standarder både med hensyn til forskningsspørgsmål og metode. Et fag, hvor enhver gør det, han eller hun har lyst til, men hvor andre måske har svært ved at se, hvad de kan bruge det til, og hvor det er svært at se, hvad fremgangen i faget er. Dette vil dermed også være noget, der gør os svagere som fagpersoner hver for sig. Derfor igen: al god forskning - og alle gode, selvstændige universitetsopgaver - begynder og slutter i fagets litteratur.

Det er også vigtigt at erkende, at krav om gode opgaver ikke blot er noget, som nogle personer fremsætter som deres private synspunkter. Bestemte arbejdsfunktioner stiller bestemte krav. BDI stiller krav til os alle. Vi skal indstille os på de krav, opgaven stiller til os - og ikke blot stille arbitrære krav til hinanden. Det kan vi naturligvis gøre på mange forskellige måder, men sigtelinjen må hele tiden være at stræbe efter at bidrage til at løse reelle problemer.

\section{Tak til}

En anonym (svensk) fagfællebedømmer, der gav en skarp analyse og værdifuldt input til artiklen.

\section{Noter}

1. En udvidet version er under udgivelse i Hjørland, 2012a.

2. En anonym fagfællebedømmer har venligt henledt min opmærksomhed på, at min skelnen mellem centripetale og centrifugale kræfter med fordel kan relateres til Becher \& Trowlers (2001) diskussioner om "convergence" og "divergence" inden for forskellige forskningsområder (jf. også Trowler, Saunders \& Bamber, 2012).

3. Hernon \& Metoyer-Duran (1993), MetoyerDuran \& Hernon (1994) og Stansbury (2002) er empiriske undersøgelser af BDI-forskeres holdninger til gode problemformuleringer inden for BDI. Disse undersøgelser synes dog mindre værdifulde end $\mathrm{fx}$ den grundige behandling af forskellige typer af opgaver i Rienecker (2005) og Rienecker \& Stray Jørgensen (2010) eller den videnskabsteoretiske behandling i Allwood \& Bärmark (1999). 
4. Alle fag, også BDI, er samfundsmæssige investeringer i vores fælles fremtid. Intet fag kan trække "frinummer" og betragte sig selv som hævet over eller stående uden for dette vilkår. Der hviler derfor et stort ansvar og et hårdt pres på os alle.

5. "Avoid what the Italians call citazionismo, a display of references that ultimately distracts from the discussion at hand by embroiling in such a labyrinth of qualifications, supplementations, and intellectual dues-paying that the main focus of the matter at hand becomes irretrievably blurred" (Innis, 2002, side vii-viii).

6. Rhoads, 2011, der belyser det amerikanske forskningsuniversitet og dets udfordringer, udgør et godt eksempel på en frugtbar teori til analyse af - $i$ al fald een type af - vidensformidlende institutioner.

7. Da det er et stort arbejde at sætte sig ind i en teori, kan der være en oplagt fare for, at man ikke slipper den igen, selv om man senere finder den problematisk, fordi man allerede har investeret megen tid $i$ at arbejde med den ("too much invested to quit").

8. Det, at afprøve en teori på et helt konkret BDIfagligt problem, kan kaldes teoriens realitetstest, og frygtelig mange viger tilbage for at lave den.

9. Jeg foreslår/foreslog ikke specifikke tidsskrifter, men den BDI-faglige litteratur, herunder de BDI-faglige tidsskrifter som generel kategori, en kategori, der naturligvis i sig selv kan og bør problematiseres.

10. Leckie; Given \& Buschman (2010): Critical theory for library and information science indeholder fx mange potentielt vigtige teorier for BDI, men får bl.a. følgende kritiske ord med på vejen af anmelder Patrick Keilty (2011): "In certain ways, however, the volume does not live up to its potential. Most of the essays are largely formulaic: introduce a theorist, summarize a few of his/her ideas, and suggest ways in which future research within information studies might engage with those ideas. With a few exceptions, the effect of such a formula is to argue persuasively for an engagement with critical theory without doing the work of that engagement in a substantive way. Most of the essays point to future potentials rather than accomplishing the tough work of such critical analysis. Where, for example, in a discussion of the importance of interpretative analysis of representation as a corrective to empirical methods, is such a sophisticated analysis of an object of representation? [...] The volume also runs the risk of encouraging what I call "theory stencil" - when one "applies" theory haphazardly, rather than treating theory as an idea that develops out of a particular structure or object under analysis. When one uses a theory as a stencil, it becomes merely instrumental, reused repeatedly to create a desired pattern of ideas that get "applied" willy-nilly to any object or structure". Et andet eksempel på en skuffende anvendelse af teori er David Blairs bog Wittgenstein, Language and Information (se anmeldelsen i Hjørland, 2007).

11. Som beskrevet i et stillingsopslag1 i 2008: "Danmarks Biblioteksforening søger en direktør med hjerte for biblioteksarbejdet og med de professionelle kompetencer, der skal til for at skabe resultater med hensyn til [punkt 1]: at fastholde og forstærke folkebibliotekernes status som et uerstatteligt element i Danmarks styrkeposition i en globaliseret verden". Hentet 2011-12-28 fra: http://www.dbf.dk/Default.aspx?ID=5347.

\section{Referencer}

Allwood, CM \& Bärmark, J (1999). The Role of Research Problems in the Process of Research. Social Epistemology, 13(1), 59-83.

Andersen, J (2011). Forsknings og undervisningsoplysninger. Hentet 2011-10-08 fra: http://pure.iva.dk/ da/persons/jack-andersen(f9d4503f-2f9b-4778-844f716434ff7008).html (Den citerede definition går flere år tilbage, jf. Internet Archive, men er her citeret fra den nuværende hjemmeside).

Audunson, R (2005). The Public Library as a Meeting-Place in a Multicultural and Digital Context. The Necessity of Low-Intensive Meeting-Places. Journal of Documentation, 61(3), 429-441.

Becher, T \& Trowler, PR (2001). Academic Tribes and Territories: Intellectual enquiry and the culture 
of disciplines (2nd Ed.) Buckingham: The Society for Research into Higher Education \& Open University Press.

Brewer, J \& Hunter, A (2006). Foundations of Multimethod Research. Synthesizing styles. 2nd ed.

Thousand Oaks, CA: Sage. (Chapter 3: Formulating research problems, pp. 39-57). http://www.sagepub. com/upm-data/6051_Chapter_3_Brewer_I_Proof_2. pdf.

Buckland, M (2012). What Kind of Science Can Information Science Be? Journal of the American Society for Information Science and Technology, 63(1), $1-7$.

Cotta-Schønberg, M (2009). En refleksion over universitetsbibliotekets fremtidsperspektiv anno 2009.

Dansk Biblioteksforskning, 5 årg.,nr. 2/3, side 5-19. http://halshs.archives-ouvertes.fr/docs/00/48/48/68/ PDF/Cotta-schoenberg.pdf.

Dahlkild, N (2011). Biblioteket i tid og rum. Arkitektur, indretning og formidling. København: Danmarks Biblioteksforening.

Diepeveen, C, Fassbender, J \& Robertson, M (2007). Indexing Software. Information Wissenschaft \& Praxis, 58(8), 413-420. http://www.cdiep-indexing.com/ IWP\%5F8\%5F2007\%5FDiep\%5FFass\%5FRob.pdf.

Hernon, P \& Metoyer-Duran, C (1993). Problem Statements: An Exploratory Study of Their Function, Significance, and Form. Library \& Information Science Research, 15(1), 71-92.

Hernon, P \& Schwartz, C (2007). What Is a Problem Statement? Library \& Information Science Research, 29(3), 307-309. http://www.lis-editors.org/bm doc/ editorial-problem-statement.pdf.

Hjørland, B (2007). Book review of Blair (2006): Wittgenstein, Language and Information: "Back to the Rough Ground!"Journal of Documentation, 63(2), 281-286.

Hjørland, B (2012a). Information Science and its Core Concepts: Levels of Disagreement. In: IbekweSanJuan, F. \& Dousa, T.M. (eds). Theories of information, communication and knowledge. A multidi- sciplinary approach. Berlin: Springer. Studies in history \& philosophy of science (in press).

Hjørland, B (2012b). Søgemaskiner og IVAs faglighed. Hentet 2012-08-27 fra http:/www.iva.dk/ omiva/nyheder/insight/12-02-23/soegemaskiner-ogivas-faglighed/.

Hjørland, B (2012c). Foreword: A Fascinating Field and a Pragmatic Enterprise. I: Bawden, D. \& Robinson, L. Introduction to information science (xxixxiii). London: Facet.

Huymans, F \& Hillebrink, C (2008). The Future of the Dutch Public Library: Ten Years on. The Hague: Netherlands Institute for Social Research.

Innis, RE (2002). Pragmatism and Forms of Sense: Language, Perception, Technics. Pennsylvania: Pennsylvania State University Press.

Jochumsen, H, Skot-Hansen, D \& Hvenegaard, C (2011). Biblioteket i byudviklingen: Oplevelse, kreativitet og innovation. København: Danmarks Biblioteksforening.

Keilty, P (2011). Book review of Leckie, Gloria J.; Given, Lisa M. \& Buschman, John E. (2010). Critical Theory for Library and Information Science. Hentet 2012-08-18 fra: http://escholarship.org/uc/ite $\mathrm{m} / 8 \mathrm{dg} 5 \mathrm{~b} 2 \mathrm{jr}$;jsessionid=AA42B6BF8897C6C9CE938 7749C90276E.

Leckie, GJ, Given, LM \& Buschman, JE (2010). Critical Theory for Library and Information Science. Exploring the Social from across the Disciplines. Westport, Conn.: Libraries Unlimited.

McKechnie, LM \& Pettigrew, KE (2002). Surveying the Use of Theory in Library and Information Science Research: A Disciplinary Perspective. $\mathrm{Li}$ brary Trends, 50(3), 406-417.

Metoyer-Duran, C \& Hernon, P (1994). Problem Statements in Research Proposals and Published Research: A Case Study of Researchers' Viewpoints. Library \& Information Science Research, 16(2), 105118.

Olausen, C (ed.) (2004). Utvärdering av ämnen arkivvetenskap, biblioteks- och informationsvetenskap, 
bok- och bibliotekshistoria, informations- och medievetenskap, kulturvård och museologi vid svenska universitet och högskolor. Stockholm: Högskoleverket. Högskoleverkets rapportserie 2004:27 R; (Heri: Appendix: En historisk och kritisk belysning av ämnet biblioteks- och informationsvetenskap (B\&I) med fokus på dess identitet och olika benämningar, side 99-135). Hentet 2011-12-26 fra: http://www. hsv.se/download/18.539a949110f3d5914ec80009366 7/0427R.pdf\#search='2004\%3A27'.

Pettigrew, KE, \& McKechnie, L (2001). The Use of Theory in Information Science Research. Journal of the American Society for Information Science and Technology, 52(1), 62-73.

Rhoads, RA (2011). The U.S. Research University as a Global Model: Some Fundamental Problems to Consider. InterActions: UCLA Journal of Education and Information Studies, 7(2). Hentet 2011-10-28 fra: http://escholarship.org/uc/item/8b91s24r.pdf.

Rienecker, L (2005). Problemformulering på de samfundsvidenskabelige uddannelser. 3. udgave. Frederiksberg: Samfundslitteratur.

Rienecker, L \& Stray Jørgensen, P (2010). Den gode opgave. Håndbog $i$ opgaveskrivning på videregående uddannelser. 3. udg. 4 opl. Frederiksberg: Samfundslitteratur.

Seidel, R (1976). Denken. Psychologische Analyse der Entstehung und Lösung von Problemen. Frankfurt \& New York : Campus Verlag.
Stansbury, MC (2002). Problem Statements in Seven LIS Journals: An Application of the Hernon/ Metoyer-Duran Attributes. Library \& Information Science Research, 24(2), 157-168. Hentet 2011-1227 fra: http://web.simmons.edu/ benoit/lis403/stansbury_2002.pdf.

Tengström, E (1993). Biblioteks- och informationsvetenskapen - ett fler- eller tvär-vetenskapligt område? Svensk Biblioteksforskning, (1), 9-20.

Trowler, P, Saunders, M \& Bamber, V (eds.). (2012). Tribes and Territories in the 21st Century: Rethinking the significance of disciplines in higher education. London: Routledge. International Studies in Higher Education.

Whitley, RR (1984). The Intellectual and Social Organization of the Sciences. Oxford: Oxford University Press. (2nd ed. with a new introduction, 2000).

Wiben Jensen, T (2011). Kognition og konstruktion: To tendenser $i$ humaniora og den offentlige debat. Frederiksberg: Samfundslitteratur.

Åström, F (2006). The Social and Intellectual Development of Library and Information Science. Doctoral thesis at the Department of Sociology, Umeå University, No 48 2006. http://www.diva-portal.org/ smash/get/diva2:145144/FULLTEXT01. 